\title{
Ethics and Ethical Theories from an Islamic Perspective
}

\author{
AL-HASAN AL-AIDAROS*, FARIDAHWATI MOHD. SHAMSUDIN \& KAMIL MD. IDRIS ${ }^{1}$
}

\begin{abstract}
With the collapse of many organizations, many researchers are increasingly paying attention to such phenomenon. But ethical issues are not always clear cut; there are many grey areas that need to be threaded with care by organizations. To determine whether an action or decision is ethically carried out, ethical theories, developed mainly by Western scholars, are the current theoretical framework organizations have at their disposal. Theories such as relativism, utilitarianism, egoism, deontology, the divine command theory, and the virtue ethics, are all products of Western understanding of what ethics are and how they are applicable to help one's decision making process. Despite their utility, this paper intends to argue that the Western concepts and understanding of what ethics are limited and incomprehensive in explaining what is right and what is wrong. In its place, this paper argues that to understand the concepts of ethics that can extend beyond time and space. It has to be analysed from an Islamic perspective. Toward this purpose, this paper will compare and contrast between Islamic and Western perspectives of ethics, and highlight the main weaknesses and limitations of the former. Then, an argument on why Islam can provide the best understanding of ethics will be made.
\end{abstract}

Keywords: Ethics, ethical theories, Islam, al-Quran, al-Sunnah

The word "ethics" originates from the Greek word "ethos", which means "character, spirit and attitude of a group of people or culture" (Loeb 1971). According to the Oxford Dictionary, ethics is defined as: (1) a system of moral principles by which human actions may be judged as good or bad, right or wrong; (2) the rules of conduct recognized in respect of a particular class of human actions.

Rachels and Rachels (1993) note that ethics represent a set of moral principles, rules of conduct or values. According to Burks (2006), the issue of ethics arises when a person has to make a decision from various alternatives relating to moral principles. Rania (2006) highlights ethics in a more general term as web relationships with others. Delaney (2005) contends that ethics is concerned with the good worth sought in life and with the rules that ought to govern human behavior and human interaction. Ogbonna and Ebimobowei (2011) state that ethics is reflected in the principles that a person uses in governing his/her actions and the personal standard by which a person distinguishes the right from the wrong. Elegido (2000) describes ethics as it is the mission for, and the understanding of, the good life, living well, a life worth living. Thus, he thinks ethics is largely a matter of perspective by putting every action and goal in its place, knowing what is important doing and what is not.

\footnotetext{
${ }^{1}$ Al-Hasan al-Aidaros*(Corresponding author), Ph.D., Senior Lecturer at Islamic Business School, College of Business, Universiti Utara Malaysia, 06010 UUM SINTOK, Kedah, Malaysia, Email: al-hasan@uum.edu.my; Faridahwati Mohd. Shamsudin, Ph.D., Assoc. Prof. at Othman Yeop Abdullah Graduate School of Business, Universiti Utara Malaysia, 06010 UUM SINTOK, Kedah, Malaysia, Email: faridah@uum.edu.my; Kamil Md. Idris, Ph.D., Professor and Dean of the School of Accountancy, College of Business, Universiti Utara Malaysia, 06010 UUM SINTOK, Kedah, Malaysia, Email: kamil@uum.edu.my.
} 
Nwagboso (2008) believes ethics is in confusion and ferment among all people and he highlights that ethics is not about what person is or what person was, or even about what person will be but ethics is about what ought and have to be. Because of that, Nwagboso (2008) thinks ethics is the standard by which person should judge action or character. On the other hand, Hayes, Schilder, Dassen and Wallage (1999) define ethics as a set of moral principles, rules of conduct or values and ethics is relevant when a person has to make a decision from different choices concerning ethical principles.

From an Islamic point of view, ethics is related to several Arabic terms. These terms are as follows: ma'ruf (approved), khayr (goodness), haqq (truth and right), birr (righteousness), qist (equity), 'adl (equilibrium and justice), and taqwa (piety). Good actions are described as salihat and bad actions are described as sayyi'at. However, the term that is most closely related to ethics in the Quran is akhlaq (Beekun 1996). Even though ethics is defined as what is right and wrong, the most pressing issue is how is one to know the right from the wrong (Velasquez 2006). To find out whether an action or behavior is ethically carried out, ethical theories are what organizations have at their disposal. Ethical theories such as relativism, utilitarianism, egoism, deontology, the divine command theory, and the virtue ethics, are all products of Western understanding of what ethics are and how they are applicable to help one's decision-making process. The next section discusses these theories and how ethics is viewed from an Islamic perspective.

\section{Ethical Theories}

With the collapse of many businesses and companies, recent research has been increasingly devoted to investigating ethical issues. This circumstance goes with the fact that the existing ethical issues are not always clear and understandable. To identify whether a behavior or decision is ethically performed, there are several ethical theories to explain what is right and what is wrong. These include relativism theory, utilitarianism theory, egoism theory, deontology theory, the divine command theory, and the virtue ethics theory. These theories are the current theoretical framework that is applied by recent research to explain an ethical phenomenon.

\section{Relativism Theory}

Relativism theory proposes that ethical values are relative to a particular environment or location. It discusses that moral values can be different from one culture to another, from one time to another (Sturgeon 2009). According to this theory, there are no moral principles that are completely right, relevant and applicable to companies and people of all countries (George 1986; Rachels et al. 1993; Velasquez 2006). This implies that: (a) different countries and societies may have different ethical codes; (b) there is no standard or principle that can be used to evaluate one societal code better than the other; (c) the ethical code of specific society has no special rank, which means it is simply one among many; (d) there is no universal truth in moral/ethical principles that can be held for all peoples at all times; and (e) the moral code of a specific country or society identifies what is right within that society; if the moral code of that country or society says that a certain action is right, then that action is right at least within that society (Rachels \& Rachels 1993).

Critics of relativism theory have argued that there are several ethical principles and values that members of any society or culture must accept if that society is to stay alive and if its members are to act together with each other efficiently. For example, all societies and cultures have norms against killing other members of the society, norms against stealing the personal goods of other members of one's society, and norms against taking bribe or involving in corruption (Velasquez 2006). Relativism theory has been criticized on this basis; because different people have different ethical viewpoints concerning some issues, it does not follow reasonably that there is no objective 
truth about that issue or that all viewpoints about that issue are equally acceptable (Velasquez, 2006). When two people or two groups have different viewpoints, theorists as well as researchers are fond of pointing out that at least one of them is wrong (Rachels \& Rachels 1993). Also, this theory would make little sense to disapprove the practices of other societies as long as their practices conform to their own principles and values. For example, practically this means that multinational companies should not be judged to act in a rightful or wrongful manner since they do so according to different prescribed cultures (Rachels \& Rachels 1993; Velasquez 2006).

From the Islamic point of view, relativism theory is also problematic. According to Islam, what is right and what is wrong cannot be left to a particular society because human beings have inherent weaknesses in that they will tend to behave in a manner that they see is convenient, regardless of whether such action is right or wrong. This is why Muslims have to base their actions on the words of Allah (the Quran) and the Sunnah of the Prophet (Al-Qaradawi 1985; Mohammed 2005). For this reason, Islam rejects relativism theory. However, Islam also respects the culture of any society as long as it is not against what is Islamically prescribed (Al-Quran 7:199). For example, the Prophet Muhammad recognizes acts such as telling the truth (Al-Quran 9:119) as morally right and rejects other acts such as killing a newborn girl as being morally wrong (Al-Quran 81:8/9).

\section{The Divine Command Theory}

Divine command theory argues that the nature of right and wrong is based on religious beliefs, which in this context refers to Jewish and Christian religions that are claimed to be divine. According to this theory, both Jewish and Christian religions define "ethically right" as being something "commanded by God", and "ethically wrong" means something "forbidden by God". In other words, ethics and religion always go together (Rachels \& Rachels 1993). Religious people commonly believe that ethics can be understood only in the context of religion. According to Rachels \& Rachels (1993), God is presented as a lawgiver who has created us, and the world we live in, for a specific purpose. However, that purpose is not absolutely understood. This theory has created some serious problems for believers and non-believers alike. Non-believers, such as atheists, reject totally the theory because they believe that God does not exist. When God does not exist, it does not make sense that ethics should be based on God's command. On the other hand, believers have problems with this theory because of etiological reasons. It is not clear, as Socrates suggested, whether a conduct is right because God commands it, or God commands a conduct because it is right. Because it is not clear in the first place why a conduct is commanded and why humankind exists in this world, the theory is rejected.

In contrast to Jewish and Christian religions, Islam makes the purpose of existence of humankind in this world clearly (Mohammed 2005). Human beings are created for the sole purpose of worshipping the One God through the engagement of good things and avoidance from engaging in wrong things (Al-Quran 51:56). Hence, for Muslims, what is right and wrong is clearly espoused through the word of Allah (Al-Quran 16: 89) and the Sunnah of the Prophet Muhammad. Based on these two important foundations, Muslims believe that a conduct is right because Allah s.w.t or His Prophet Muhammad has commanded it. Muslims believe and accept Allah's commandment of what is right and wrong because Allah s.w.t knows everything, including what is the best for the people (Al-Quran 58:7; Al-Qaradawi 1985; Mohammed 2005). 


\section{Consequences Theories}

Consequence theories, utilitarian theory and egoism theory, look at the consequences of any action to determine whether an act is right or wrong. In utilitarian theory, an act is considered to be morally right if it brings the greatest good for the greatest number. An action must do the most good and does the least harm (Lavan \& Martin 2008). In contrast, egoism theory is concerned about the consequences of the greatest good for the person only without considering the consequences on others. The next section will discuss these theories in more detail.

\section{Egoism Theory}

The general idea of egoism theory is that one must always perform in his/her own interest (Ho 2007). An action is considered to be morally right when it promotes a person's self-interests more than the interests of others. In other words, egoism theory assumes that each person ought to follow his/her own self-interest exclusively. This means that a person does not have an ethical duty except to do what is best for him/her (Rachels \& Rachel 1993). So, the only ultimate standard of conduct is the standard of self-interest, and this standard involves a person's natural duties and obligations.

Conversely, Baier (1958) argues that egoism theory cannot be right because it cannot explain conflict of interests. Also, the theory fails to justify the ethics of altruism (Velasquez, 2006). Furthermore, the theory would have each person assigned greater importance to his/her interests than to the interests of others. But there is no general difference between oneself and others to which each person can appeal, which justifies the difference in treatment. As a result, critics argue that egoism theory is unacceptably logical because people must care about the interests of other people for the same reason they care about their own interest (Rachels \& Rachel 1993). Armstrong (1993a) indicates that egoism theory is relevant to business schools as businesses are in search of maximization of profits as their prime objective. However, this theory repeatedly results in conflict of interest and cannot always be adapted to the mission of serving public and clients' interests like in the accounting profession. Moreover, egoism theory might be in conflict with the principles of accountants' ethical code of conduct as accountants must have objectivity, integrity, due care, and protect public interest. Consequently, egoism theory has its limitation as a sufficient ethical theory for accountants (Duska \& Duska 2003; Ho 2007; Koehn 2005). Egoism theory is not acceptable in Islam because it is essentially against the Islamic principles of justice, helping others, and altruism. According to Prophet Muhammad, a Muslim has no iman (faith) until he loves his brother as he loves himself (Al-Qaradawi 1985). Muslims are strongly encouraged to be considerate and help others without looking for material rewards from the society. Doing so, they will receive rewards in the Hereafter as Allah promised and mentioned in several places in the Quran $(5: 54 ; 48: 29 ; 59: 9$; 107:3).

\section{Utilitarian Theory}

Utilitarianism is a common term for any view that holds that procedures and actions should be evaluated on the basis of the benefits and costs they impose on society. Utilitarian theory argues that a behavior is considered morally right when it results in a greater number of utilities than it could be achieved by any other action (Sturgeon 2009). Utilitarian theory and egoism theory both consider the consequences of an action with different approaches of evaluating an ethical conduct. Egoism theory focuses on the consequences for the self, whereas utilitarian theory focuses not only for the self but also for as many as possible. Besides, utilitarian theory uses cost-benefit analyses to 
judge a morally acceptable behaviour and states that people should act to create the greatest good for the greatest number of people (Ho 2007; Rachels \& Rachel 1993; Velasquez 2006).

Utilitarian theory has been criticized because it is difficult to prove what counts as value or good. One's good may be another's bad and vice versa (Duska et al. 2003; Ho 2007; Koehn 2005). Moreover, professionals such as accountants and managers may find it difficult to define the best for all stakeholders (Ho 2007). As a result, it will be a challenge for professionals to determine what is best because the future is constantly changing. Also, critics argue that utilitarian theory fails to preserve the human rights and justice. This is because this theory focuses only on the consequences. For example, if a person robs a bank to help poor people, such action is considered ethical from the utilitarian perspective (Velasquez 2006).

Generally speaking, Islam does not accept any wrong doing, for example, stealing or cheating, regardless of whether it brings greater good for the society or not. In view of that, Islam does not accept utilitarian theory as a sufficient theory because this theory considers ethics as having the greatest consequences for the greatest number, when some actions may be inherently wrong. From the Islamic perspective, Muslims must follow the right ethics in accordance to Islamic principles (Al-Quran 59:7). The Islamic system takes care of the interests of everyone in the society because of the universal ethical values and principles imposed by the religion (Al-Qaradawi 1985; Mohammed 2005).

\section{Deontology Theory}

Deontology theory underlines duty as a basic moral category. This theory also focuses on universal statements of right and wrong. However, unlike utilitarian theory, this theory is not concerned with the consequences of the action, which means that the action is independent in itself (Ho 2007). In other words, the theory argues that a person has a duty to do what is right without having to consider the consequences of his/her action (Ho 2007). The most representative supporter of deontology theory is Immanuel Kant, a German philosopher in the $18^{\text {th }}$ century. Kant believed that there are universal ethics that everyone must accept, for example, "never do something unless you are willing to have everyone done it" (Velasquez 2006). Another example of Kant's universal ethics is "Never use people merely as means, but always respect and develop their ability to choose for themselves".

Critics such as Velasquez (2006) argue that deontology theory's categorical imperatives are unclear because the theory only considers the duty or the action independently without looking at the consequences. It can be in conflict with the normative understanding of people and sometimes it implies some mistaken ethical conclusions (Velasquez 2006). In applying deontology theory to accounting practices, professional accountants may find it difficult to deal with the conflict of duties for different stakeholders (Armstrong 1993). Thus, they may assess the consequences and perform the one which has the least harm or the greatest benefit to his or her self-interests. When this happens, the action of professional accountants can be evaluated against egoism theory or utilitarian theory to solve the conflict eventually (Armstrong 1993). In addition, deontology theory might have difficulty explaining the reasons for undertaking an action if that action will not result in good consequences.

Deontology theory is also not acceptable in an Islamic context because the only lawgiver for the overall system, including the ethical system, is Allah s.w.t (Al-Quran 16:86). The Prophet Muhammad (peace and prayers be upon him) advised his followers (or sahabah) to treat others as how they like others to treat them (Mohammed 2005). Furthermore, Islam encourages Muslims not only to treat people with justice but to treat others better than how they treat them. Allah s.w.t says in the Quran (41:34): "Nor can goodness and evil be equal. Repel (evil) with what is better". 


\section{Virtue Ethics Theory}

Virtue ethics theory defines what is right and wrong based on specific traits and values every person must follow. According to this theory, the purpose of an ethical life is to develop general characters called ethical virtues, and to apply and exhibit them in reality (Velasquez 2006). Unlike previous theories such as consequences theories and deontology theory that are concerned about an individual's action, virtue ethics theory focuses on the self (Ho 2007). Virtue ethics theory concentrates on the question of what people should be rather than of what they should do. In other words, this theory focuses on what makes a good individual or person rather than what makes a good action (Lavan et al. 2008). The most representative supporter of virtue ethics theory is Aristotle. Aristotle proposed several virtue traits that every person must have. They are civility, cooperativeness, courage, fairness, friendliness, generosity, honesty, justice, loyalty, self-confidence, self-control, modesty, fairness, and tolerance (Rachels et al. 1993). Virtue ethics theory has limitations to answer question like what are the sources of these ethics (Velasquez 2006). In addition, loyalty ethic, as a product of this theory, may guide to conflict with the requirements of the accounting profession for being independent (Duska et al. 2003; Koehn 2005).

Furthermore, as different stakeholders may have different opinions regarding accounting practices, there may be conflicting virtues traits that accountants should consider, and it is difficult for professional accountants to resolve these conflicts (Duska et al. 2003). Even though there are some criticisms in the application of virtue ethics theory, it still plays a significant role in accounting practices. Based on the idea of virtue ethics theory, the American Institute of Certified Public Accountants (AICPA), as well as other accounting organizations around the world, established an ethical code of conduct which constitutes the expected virtue ethics for professional accountants. These virtue ethics are translated in to the principles and rules of accountants' ethical code of conduct (Ho 2007; Velasquez 2006).

In contrast, Islam considers both ethical actions and virtue ethics, not just only one criterion as contended by virtue ethics theory that is based on the character (Mohammed 2005). In Islam every person must behave according to specific ethical characteristics, but the sources of these characteristics are Quran and Sunnah (Prophet Muhammad's saying, practice and approvals) (AlQuran 31:77; Mohammed 2005). Besides, in Islam, individuals have a very clear picture about what is right and wrong as enshrined in the Quran and Sunnah (Al-Qaradawi 1985; Al-Quran 58:7).

As a summary, to determine whether an action or decision is ethically carried out, ethical theories, developed mainly by Western scholars, are the current theoretical framework organizations have at their disposal. Theories such as relativism, utilitarianism, egoism, deontology, and the virtue ethics, are all products of Western understanding of what ethics are and how they are applicable to help one's decision-making process. Every theory has a single viewpoint with regard to ethical issues, as shown in Figure 1 like action, character, religion, or culture.

However, despite their utility, this study argues that the Western concepts and understanding of ethics are limited and incomprehensive in explaining what is right and what is wrong. Indeed, Velasquez (2006) concludes that there is no absolute ethical theory that is able to provide sufficient explanation about what ethics is. In addition, nor ethical philosophers are able to provide a universal rule or standard that could explain when considerations of justice, for example, become important enough to outweigh infringements on conflicting right or consequences of action. In other words, ethical theorists have been unable to agree on any comprehensive system for making such moral judgments.

In contrast, as shown in Table 1, Islam conceptualizes ethics based on the Islamic sources. Islam goes even further than these theories by maintaining that all systems, including the ethical system, are in the hands Allah s.w.t. While Islam agrees with divine command theory, which was rejected in the Western ethical literature, it has different considerations as mentioned earlier. In 
order to get a clear understanding of ethics from the Islamic perspective, the next section will explain a general framework of ethics in Islam. The main idea of the Islamic ethical theory is that the Islamic sources are the only standard for identifying what is right and what is wrong:

Figure 1 : Summary of Ethical Theories

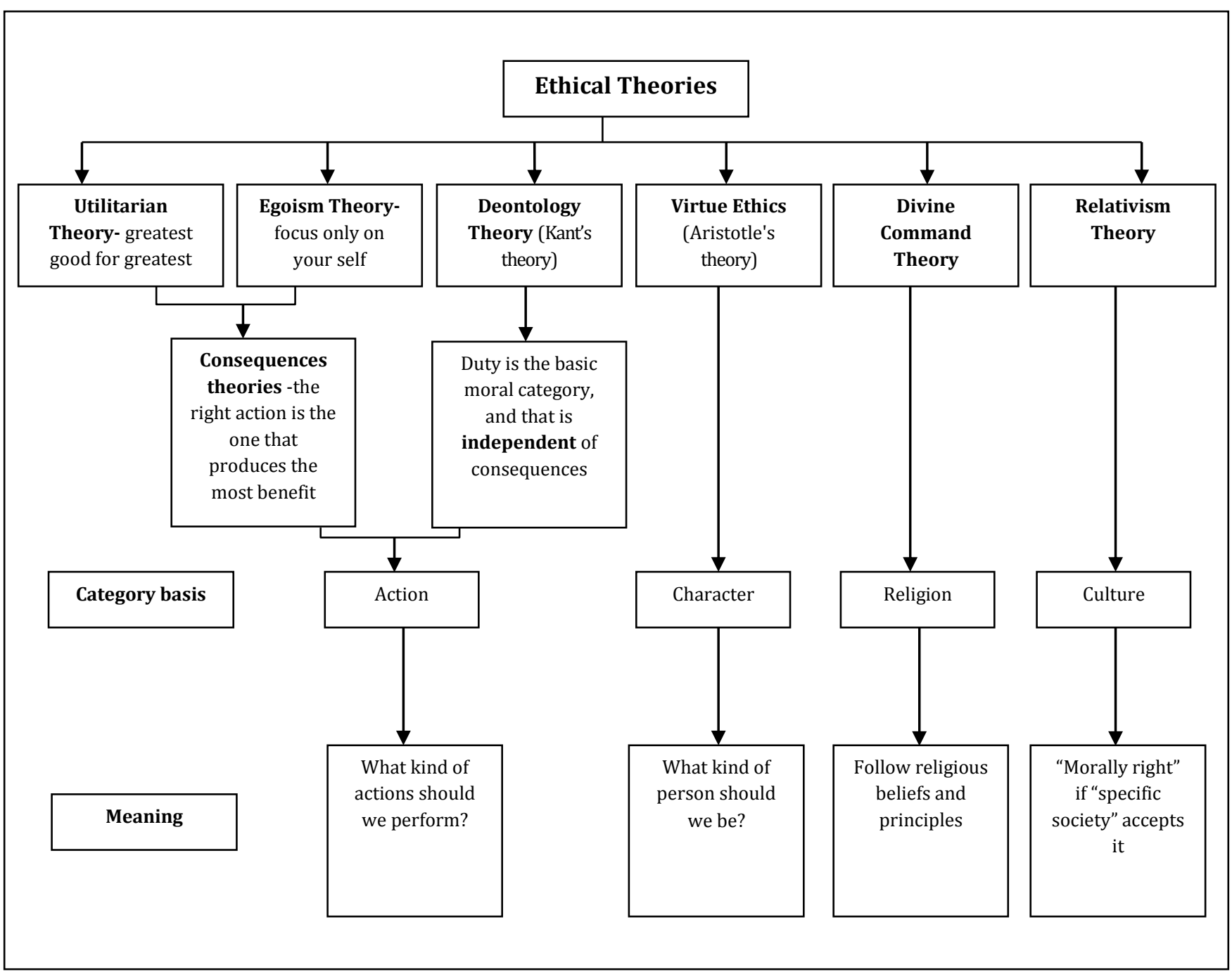

https://doi.org/10.24035/ijit.4.2013.001 
Table 1: Ethical Theories and Islamic Perspective

\begin{tabular}{|c|c|c|}
\hline Theory & Main Idea & Islamic Perspective \\
\hline $\begin{array}{l}\text { Relativism } \\
\text { theory }\end{array}$ & $\begin{array}{l}\text { Ethics are relative to a particular environment. } \\
\text { Different societies may have different ethical } \\
\text { codes. There is no universal truth in ethical } \\
\text { principles that can be held by all peoples at all } \\
\text { times. }\end{array}$ & $\begin{array}{l}\text { Rejected because may be a } \\
\text { particular society culture is against } \\
\text { Islamic principles. }\end{array}$ \\
\hline $\begin{array}{l}\text { Divine } \\
\text { Command } \\
\text { theory }\end{array}$ & $\begin{array}{l}\text { "Ethically right" means "commanded by God", and } \\
\text { "ethically wrong or unethically" means "forbidden } \\
\text { by God". Religion is the only standard to identify } \\
\text { ethics. }\end{array}$ & $\begin{array}{l}\text { Accepted, but this theory was } \\
\text { rejected in the Western literature. }\end{array}$ \\
\hline $\begin{array}{l}\text { Utilitarian } \\
\text { theory }\end{array}$ & $\begin{array}{l}\text { "Ethically right" means the action results in a } \\
\text { greater number of utilities than could be achieved } \\
\text { by any other actions. }\end{array}$ & $\begin{array}{l}\text { Rejected because the only basis for } \\
\text { this theory is the greatest } \\
\text { consequences for greatest number. }\end{array}$ \\
\hline $\begin{array}{l}\text { Egoism } \\
\text { theory }\end{array}$ & $\begin{array}{l}\text { A person must always perform in his/her own } \\
\text { interest. An action is considered to be ethically } \\
\text { right only when it promotes a person's self- } \\
\text { interests. }\end{array}$ & $\begin{array}{l}\text { Rejected because it is against the } \\
\text { Islamic principles of justice, } \\
\text { helping others, and altruism. }\end{array}$ \\
\hline $\begin{array}{l}\text { Deontology } \\
\text { theory }\end{array}$ & $\begin{array}{l}\text { It underlines the duty as a basis of moral category } \\
\text { which can be seen as a right or wrong judgment. It } \\
\text { does not look at the consequences of action. And, } \\
\text { there are universal ethical actions that everyone } \\
\text { must accept. }\end{array}$ & $\begin{array}{l}\text { Rejected because the theory is not } \\
\text { clear about the source of these } \\
\text { "universal ethics" since in Islam } \\
\text { the only source for ethical system } \\
\text { is the Islamic principles. }\end{array}$ \\
\hline $\begin{array}{l}\text { Virtue ethics } \\
\text { theory }\end{array}$ & $\begin{array}{l}\text { This theory focuses on what makes a good } \\
\text { individual or person rather than what makes a } \\
\text { good action. There are specific virtue traits that } \\
\text { every person must have such as civility, } \\
\text { cooperativeness, courage, fairness, friendliness, } \\
\text { generosity, honesty, justice, loyalty, self- } \\
\text { confidence, self-control, modesty, fairness, and } \\
\text { tolerance. }\end{array}$ & $\begin{array}{l}\text { Rejected because the only basis for } \\
\text { this theory is virtue ethics. }\end{array}$ \\
\hline
\end{tabular}

\section{Islamic Perspective on Ethical Issues}

Many Muslim scholars have written about ethical issues based on the main Islamic sources, which are Quran and Sunnah. This study focuses on scholars such as Ahmad (2003), al-Banna (1940), alGhazali (2001), al-Qaradawi (1985, 1994, 1996), Mawdudi (1977), Mohammed (2005), and Yaken (2006). This is because they connect their works and writing about Islamic ethics with the Western environment in a way which makes the comparison between Islam and the Western perspective easier and more appropriate.

In Islam, ethics can be defined as the good principles and values based on the Islamic sources (Mohammed 2011). These ethics are consistent with the ability of human beings (AlGhazali 2001). It also covers all aspects of life (Al-Qaradawi 1994). It is important to highlight the 
importance of ethics in Islam when discussing ethical issues. Islamic worships, which can be defined as religious deeds and actions ordered by Allah s.w.t to get His acceptance (Yaken, 2006), are designed to improve and protect ethics (Al-Banna 1940; Al-Qaradawi 1985, 1994, 1996). Prayer refrains one from indecency and evil. Allah s.w.t says: "And establish regular prayer, for prayer restrains from shameful and unjust deeds" (Al-Quran 29:45). Zakat is taken from the rich to be given to the poor in order to sanctify the former and clean them from their sins. Allah s.w.t further says: "Of their goods, take alms, that so thou mightiest purify and sanctify them" (Al-Quran 9:103). Fasting teaches Muslims how to live with ethical principles and values. The Prophet Muhammad (peace and prayers be upon him) said: "Whoever does not give up false speech and acting upon it and does not give up offensive speech and behaviour, Allah has no need of his giving up his food and drink". Allah s.w.t also says: "Fasting does not mean abstaining from food and drink only; rather it is also abstaining from lying, falsehood and idle speech" (Al-Ghazali 2001). The pilgrimage (Hajj) trains Muslims to develop characteristics like patience, endurance, and altruism. Allah s.w.t says: "For Hajj is the months well known, if anyone undertakes that duty therein, let there be no obscenity, nor wickedness, and nor wrangling" (Al-Quran 2:197). In sum, the Prophet (peace and prayers be upon him) indicated that the main purpose Allah sent him to the people is to improve their ethics. He said: "I have been sent to accomplish the best of the morality" (Al-Ghazali 2001).

Ethics is related to faith (iman). Iman is the religious feelings that result from following what Allah s.w.t asks Muslims to do (Al-Banna 1940). Iman is the power that improves and protects ethics (Al-Qaradawi 1994; Mawdudi 1977; Yaken 2006) and Iman is not acceptable in the eyes of Islam without connecting it with good deeds (Al-Ghazali 2001). It means that strong faith generates a good character and weak faith results in a collapse of morality. The Prophet Muhammad (peace and prayers be upon him) connects faith (iman) with ethics. He mentioned "None of you (truly) has faith until he loves for his brother what he loves for himself" (Yaken 2006). The Prophet (peace and prayers be upon him) was told about a woman who prayed and fasted constantly, but she used to hurt her neighbors with her words. The Prophet (peace and prayers be upon him) said that the woman would go to hell in the hereafter (Al-Ghazali 2001). The Prophet also said "Let he who truly believes in Allah and the Last Day speak good or be silent" (Al-Qaradawi 1985). The Prophet asked his companions "Do you know who the bankrupt is?" His companions replied, "The bankrupt among us is the one who has neither money with him nor any property." The Prophet (peace and prayers be upon him) said, "The real bankrupt of my ummah would be he who would be resurrected with much of his prayer, fasting, and sadaqah. But he will still find himself bankrupt on that Day as he will have exhausted the funds of virtues because he reviled others, brought calumny against others, unlawfully devoured the wealth of others, shed the blood of others, and beat others; so his virtues would be credited to the account of those who suffered at his hand. If his good deeds fall short to clear the account, their sins would be entered in his account and he would be thrown in the Hellfire (Yaken 2006). The Prophet (peace and prayers be upon him) said "The most complete believers in iman (faith) are those who are best in character" (Al-Ghazali 2001).

In Islam, the essential rule in business is honesty and fair dealing, and a businessman should, as a result, be a person of high ethical principles (Kaliffa 2003). The market should be free and not subject to manipulation and where individuals engaging in trade and commerce should act fairly (Lewis 2006). Dealing in stolen goods is forbidden (Al-Qaradawi 1994). Advertisement is not encouraged when the intention is to force up the price in times of scarcity and so profit at the expense of others (Lewis 2006). Because Islam has several characteristics (for instance, comprehensive, realistic, and balanced), ethics in Islam are naturally influenced by these characteristics. The next section will discuss the characteristics of Islam. 


\section{Characteristics of Islamic Principles}

Ahmad (2003) defines Islam as a set of norms, values and laws that make up the Islamic way of life. The main components of Islam are iman (faith), akhlaq (ethics), and fiqh, which is the legal rulings that govern the acts of human beings (Mawdudi 1977). The first two components i.e. iman (faith) and akhlaq (ethics) are permanent and fixed at all times and for all societies. In contrast, the last component that is fiqh may be modified and changed consistently with time and place. Islam offers systems in various areas of science, finance, and society. Islam is also flexible and applicable in the environment of changing times (Al-Qaradawi 1985; Mawdudi 1977; Yaken 2006).

\section{Comprehensive}

Islam is very clear in everything related to this world. Islam provides guidance for Muslims in every situation (Al-Ghazali 2001; Al-Qaradawi 1994). Al-Banna (1940) defines the message of Islam as the message that extends across time and covers all matters of this world and the Hereafter. The Quran is the book that guides people because it is from Allah s.w.t, who has created this world and who knows what is the right and wrong (Al-Qaradawi 1994; Yaken 2006). Allah s.w.t told His Prophet Muhammad (peace and blessings be upon him) that Quran is comprehensive covering all aspects of life. He said: "We have sent down to thee the Book explaining all things" (Al-Quran 16:89). Ethics from an Islamic viewpoint are not simply religious morality reflected in the performance of some practices such as praying, not eating pork, and not consuming alcohol. But ethics cover all aspects of life, physically, morally, spiritually, in secular form, intellectually, emotionally, individually, and collectively (Al-Banna 1940; Al-Qaradawi 1996; Yaken 2006). Islam has a comprehensive perspective to ethics by taking a full picture of everything related to human being; it does not consider a single standard only such as the consequences of actions as argued by utilitarian theory and egoism theory. Moreover, Islamic principles are not against scientific facts and logical theories, whether they are proposed by Muslim or non-Muslim scientists (Al-Qaradawi 1996; Mawdudi 1977).

There are at least three types of ethics in society: ethics that are related to individuals, family, and society. Ethics related to individuals include things such as Muslims must take care of themselves by eating and drinking without wasting. Allah s.w.t says: "Eat and drink: But waste not by excess, for Allah loveth not the wasters" (Al-Quran 7:31). Honesty, restraint and self-purity, trust, truth, chastity, modesty and integrity, are examples of individual ethics (Mohammed, 2005). In addition, there are ethics related to family. For example, a husband must treat his wife in a polite and ethical manner. Allah s.w.t says: "Live with them (your women) on a footing of kindness and equity" (Al-Quran 4:19). Islam strongly advises children to take care of their parents. The Quran (46:15) says: "We have enjoined on man kindness to his parents". Islam prohibits parents from killing their children for fear of poverty as Allah s.w.t says: "Do not kill your children for fear of poverty: We shall provide sustenance for them as well as for you, the killing of them is a great sin" (Al-Quran 17:31). Respect of parents, showing kindness to little ones, and justice in dealing with children are examples of the ethics related to the family (Mohammed 2005). Furthermore, there are ethics related to society in general. For example, Islam provides guidance on the etiquette of entering other people's house. Allah s.w.t says: “Do not enter others' houses until you have asked permission and saluted those in them: that is best for you, in order that you may heed" (Al-Quran 24:27). With regards to economics, Allah s.w.t says: "Woe to those that deal in fraud. Those who, when they have to receive by measure from men, exact full measure. But when they have to give by measure or weight to men, give less than due" (Al-Quran 83:1/2/3). In politics and government, Allah s.w.t says: "Allah command you to render back your trusts to those to whom they are due; and when you judge between man and man, that you judge with justice" (Al-Quran 4:58). The virtue of 
cooperation, protecting the privacy of others, refraining from gossip, prohibition of robbery, prohibition of fraud, prohibition of injustice, spreading brotherhood, friendship, and love among all members of society are examples of ethics related to society in general (Mohammed 2005).

In Islam, the Quran is the main course of judgment. However, because the Quran generally speaks about general concepts, the specific details of them are spelled out by the Sunnah. In the case of ethics, the detailed practicality of what ethics is embodied in the Prophet's action and behavior. Indeed, the Prophet Muhammad (peace be upon him) explained the purpose of his mission. He said: "I was sent only to perfect the moral excellence of human beings" (Al-Ghazali 2001). Hence, to know how ethics should be applied, Muslims need to look no further than to the Prophet himself. Ethics is a very broad topic that goes beyond this study. Since the focus here is on accounting, the discussion is limited to ethical issues that are related to the principles of professional accountants only.

\section{Realistic}

Being realistic is one of the characteristics of Islam. The Islamic principles take into account people's ability to implement things (Al-Banna 1940; Al-Qaradawi 1996). From the ethical point of view, Islam takes into account the capacity that people have because Allah s.w.t has knowledge of the weaknesses and strengths of mankind (Al-Qaradawi 1994). In Islam, justice is a fundamental principle, as the Quran (42:40) reports: "The recompense for an injury is an injury equal thereto (in degree)", however, Muslims are encouraged to forgive those who did wrong to them and be patient, as Allah s.w.t says: "but if a person forgives and makes reconciliation, his reward is due from Allah, for (Allah) loves not those who do wrong" (Al-Quran 42:40). Moreover, Allah s.w.t says: "And if you do catch them out, catch them out no worse than they catch you out: But if you show patience, that is indeed the best (course) for those who are patient" (Al-Quran 16:126).

Islam recognizes that different people have different degrees of iman (faith). The Quran (35:32) says: "Then we have given the book of inheritance to such of our servants as we have chosen: but there are among them some who wrong their own souls; some who follow a middle course; and some who are, by Allah's leave, foremost in good deeds; that is the highest Grace." In addition, Islam considers and takes into account special circumstances that allow Muslims to engage in acts that are originally prohibited under normal circumstance such as lying to mislead the Muslims' enemy during a war time (Al-Qaradawi 1996). Another example is that Islam also allows a Muslim to drink alcohol if he has no other viable choice such as when he is likely to die when surrounded in a desert and there is no water available (Al-Qaradawi 1985).

\section{Moderation or Balance}

Islam takes a moderate approach in ethics as opposed to the ultra-idealists who see a human being as an angel and the ultra-realists who perceive a human being as an animal (Al-Banna 1940). In the eyes of Islam, human beings are created with both the need of body and spiritual soul (Al-Ghazali 2001). Also Islam has a moderate view of this life as opposed to those who deny the existence of hereafter, and those who deny inhabiting and developing this life (Al-Qaradawi 1985). Islam recognizes that there is life to be lived in this world as well as life in the hereafter, but goes further by saying that this life is the way to the life in the hereafter; and life in the hereafter is far more important than life in this world (Al-Ghazali 2001). Nevertheless, Muslims believe that living his/her life by working hard is the purpose of the creation of human beings, and worship of God (Allah). The Quran (2:201/202) says: "And there are men who say: "Our Lord! Give us good in this world and good in the hereafter, and defend us from the torment of the fire. To these will be allotted what they have earned; and Allah is quick in account". 
It can be concluded that, ethics are defined as what is right and wrong. Several theories define ethics based on different standards. Every theory has a single viewpoint with regard to ethical issues like action, character, religion, or culture. The Western concepts and understanding of ethics are incomplete in explaining what is right and what is wrong. In contrast, Islam has a comprehensive perspective regarding the ethical issues because the lawgiver for all systems, including the ethical system, is Allah s.w.t, who knows everything and what is best for all human beings. Ethics in Islam are defined as the good principles and values based on the Islamic sources. The Islamic sources are the only standards for identifying what is right and what is wrong. The Islamic ethics and Islamic sources have different characteristics that make the Islamic perspective more appropriate to explain ethics. These characteristics are comprehensiveness, realism, and balance. Ethics in Islam are consistent with the ability of human beings and they cover all aspects of life.

\section{References}

Ahmad, K. 2003. The Challenge of Global Capitalism: An Islamic Perspective. Making Globalization Good: The Moral Challenge of Global Capitalism. Oxford: Oxford University Press.

Al-Banna. 1940. Messages' Group of Imam Hasan al-Banna (1st ed.). Alexandria: Darul Al-D’aoah Publication.

Armstrong, M. 1993. Ethics and Professionalism or CPAs. Ohio: South-Western Publication.

Armstrong, M. 1993a. Ethics And Professionalism in Accounting Education: A Sample Course. Journal of Accounting Education 11(1): 77-92.

Baier, K. 1958. The Moral Point of View: A Rational Basis of Ethics. New York: Cornell University Press.

Beekun, R. 1996. Islamic Business Ethics. Nevada: University of Nevada.

Burks, B. 2006. The Impact of Ethics Education and Religiosity on the Cognitive Moral Development of Senior Accounting and Business Students in Higher Education. Unpublished doctoral thesis. Nova Southeastern University, USA.

Chan, K. C., Fung, H. G., \& Yau, J. 2010. Business Ethics Research: A Global Perspective. Journal of Business Ethics 95(1): 39-53.

De George, R. 1986. Business Ethics. Journal of Business Ethics, 5 (6): 421-432.

Delaney, J. 2005. The Impact of Ethics Education on the Moral Reasoning Ability of Accounting Students. Unpublished doctoral thesis. Ambrose University, USA.

Duska, R., \& Duska, B. 2003. Accounting Ethics (1st ed.). New York: Wiley-Blackwell.

Elegido, J.M. 2000. Fundamental of Business Ethics: A Developing Countries Perspective. Lagos: Spectrum Books Ltd.

Al-Ghazali. 2001. Muslim's Morality (16th ed.). Beirut : Darul Al-Qalam Publication.

Hayes, R., A. Schilder, R. Dassen \& P. Wallage. 1999. Principles of Auditing: An International Perspective. Berkshire: McGraw-Hill Publishing Company.

Ho, Y. 2007. Undergraduate Accounting Students' Perceptions of Accounting Ethics: A Cross-Culture Comparative Study. Unpublished doctoral thesis. University of Minnesota.

Kaliffa, A.S. 2003. The Multidimensional Nature and Purpose of Business in Islam. The Islamic Perspective Journal 7(1\&2): 1-25.

Koehn, J. 2005. Accounting Ethics. Business Ethics Quarterly 15(3): 517-521.

Lavan, H. \& Martin, W. 2008. Bullying in the US Workplace: Normative and Process-oriented Ethical Approaches. Journal of Business Ethics 83(2): 147-165.

Lewis, K. 2006. Accountability and Islam. Proceedings of the Fourth International Conference on Accounting and Finance in Transition. Australia: University of South Australia. 
Loeb, S. 1971. A Survey of Ethical Behavior in the Accounting Profession. Journal of Accounting Research 9(2): 287-306.

Mawdudi. 1977. Life's System in Islam (7th ed.). Beirut: Darul Al-Ressalh Publication.

Mohammed, A. 2011. The Role of Yemeni Accountants in Fighting Corruption. The Legal Accountant 15(9): 30-37.

Mohammed, A. 2005. The Relationship between Islamic Rules and Accountants' Ethics. Unpublished manuscript. Yemen: Hadhramout.

Nwagboso, J. 2008. Professional Ethics, Skill and Standards. Jos, Nigeria: Inspirationz Media Konsult, Maiden Edition.

Ogbonna, G., \& Ebimobowei, A. 2011. Ethical Compliance by the Accountant on the Quality of Financial Reporting and Performance of Quoted Companies in Nigeria. Asian Journal of Business Management 3(3): 152-160.

Al-Qaradawi, Y. 1985. The Iman (Faith) and Life. Doha: Arabia Publication. Retrieved October 15, 2009, from www.daawa-info.net.

Al-Qaradawi, Y. 1994. The Priorities of Understanding. Beirut: Darul Al-Ressalh Publication. Retrieved October 15, 2009, from www.fiseb.com.

Al-Qaradawi, Y. 1996. The General Characteristics of Islam (9th ed.). Beirut: Darul Al-Ressalh Publication.

Rachels, J. \& Rachels, S. 1993. The Elements of Moral Philosophy. New York: McGraw-Hill.

Rania, A. 2006. Business Ethics as Ethics as Competitive Advantage for Companies in the Globalization Era. New York : Social Science Research Network.

Sturgeon, N. 2009. Moral Disagreement and Moral Relativism. Social Philosophy and Policy 11(1): 80-115.

Velasquez, M. 2006. Business Ethics: Concepts \& Cases (6th ed.). London: Person Education International.

Yaken. 2006. What is the Meaning of My Belong to Islam? Beirut: Darul Al-Ressalh Publication. 